\title{
Sprawozdanie z Konferencji Naukowej „Prawno-administracyjne i finansowe aspekty bezpieczeństwa wewnętrznego państwa wobec aktualnych problemów migracyjnych", Stężnica k. Baligrodu, 28-29 lutego 2016 r.
}

W dniach 28-29 lutego 2016 r. w Stężnicy k. Baligrodu odbyła się Konferencja Naukowa "Prawno-administracyjne i finansowe aspekty bezpieczeństwa wewnętrznego państwa wobec aktualnych problemów migracyjnych". Jej współorganizatorami byli: Katedra Prawa Publicznego, Katedra Prawa Konstytucyjnego, Zakład Prawa Finansowego i Zakład Prawa Policyjnego Wydziału Prawa i Administracji Uniwersytetu Rzeszowskiego (UR). Udział w niej wzięli przedstawiciele Policji, Żandarmerii Wojskowej, administracji rządowej i samorządowej, Państwowej Inspekcji Pracy oraz pracownicy naukowi i przedstawiciele studentów Wydziału Prawa i Administracji UR, pracownicy naukowi Politechniki Rzeszowskiej, KUL i Wyższej Szkoły Informatyki i Zarządzania w Rzeszowie.

Uroczystego otwarcia konferencji i przywitania przybyłych gości dokonali prof. zw. dr hab. Stanisław Sagan - dziekan Wydziału Prawa i Administracji oraz prof. zw. dr hab. Stanisław Pieprzny - kierownik Zakładu Prawa Policyjnego, podkreślając wagę tematu będącego przedmiotem obrad we współczesnym świecie oraz wpływ zjawisk migracyjnych na bezpieczeństwo państwa oraz bezpieczeństwo i porządek publiczny. Mówcy przedstawili też krótko historię, przyczyny i rodzaje migracji.

Obradom w pierwszej części przewodniczyła prof. zw. dr hab. Elżbieta Ura kierownik Katedry Prawa Publicznego, zwracając uwagę, że w konferencji udział biorą nie tylko pracownicy naukowi różnych dyscyplin naukowych (prawa administracyjnego, karnego, socjologii, politologii) zajmujący się zagadnieniami szeroko rozumianego bezpieczeństwa wewnętrznego państwa, ale także praktycy. Współpraca z praktykami wpisuje się już jako stały element organizowanych konferencji na temat bezpieczeństwa wewnętrznego państwa. Wystąpienia w tej części mieli: dr hab. prof. UR Elżbieta Feret - kierownik Zakładu Prawa Finansowego WPiA UR i dr hab. prof. KUL Marcin Szewczak - kierownik Katedry Prawa Unii Europejskiej KUL w Lublinie. Prof. E. Feret zwróciła uwagę na „Podstawy ustrojowe i finansowe konsekwencje zjawiska migracji”, prowadząc rozważania "na tle porównawczym Polski i Niemiec". Odnosząc się do migracji w Niemczech, przedstawiła dane dotyczące problemów migracyjnych przygotowane przez niemieckich studentów w ramach Polsko-Niemieckiego Seminarium Naukowego, które odbyło się w Hochschule für 
öffentliche Verwaltung Kehl pod koniec 2015 r. Zwróciła uwagę, że ocenie poddać należy istnienie nie tylko migracji, ale też zjawisk migracyjnych, rozumiejąc pod tym pojęciem zarówno docieranie do prawdziwych przyczyn migracji ludzi, tworzenie podstaw prawnych ułatwiających ich przyjmowanie, zapewnianie migrantom "godziwych" warunków życia, jak i ochronę tożsamości państwa przyjmującego oraz konieczność przewidywania następstw zbyt dużej migracji. Wszystko to zaś należy wiązać ze środkami finansowymi, które mają zabezpieczyć właściwe traktowanie migrantów, a co za tym idzie - każde państwo musi przewidywać w swoich budżetach środki finansowe niezbędne na zaspokojenie podstawowych potrzeb osób migrujących legalnie. Ponadto konieczne jest wyposażenie budżetu w środki pieniężne mające przeciwdziałać migracji nielegalnej, czyli sfinansowanie działalności służb odpowiedzialnych za zabezpieczanie granic państwa. Tutaj także najważniejszą rolę odgrywają unormowania prawne i ich harmonizacja z przepisami państw europejskich.

Prof. M. Szewczak, przedstawiając „Prawne aspekty bezpieczeństwa wewnętrznego państw Grupy Wyszehradzkiej w obliczu kryzysu migracyjnego", zwrócił uwagę na zagrożenia bezpieczeństwa tzw. szlaku bałkańskiego, którym do Europy przybywają migranci, wynikające z migracji z Bliskiego Wschodu oraz stanowiska państw Grupy Wyszehradzkiej w odniesieniu do migrantów.

Na zakończenie tej części obrad głos zabrał wicestarosta leski Wiesław Kuzio, prezentując slajdy ukazujące "System zarządzania kryzysowego w powiecie leskim”, organizację ćwiczeń i szkoleń w tym zakresie i przygotowania powiatu leskiego do przeciwdziałania zagrożeniom bezpieczeństwa publicznego. Odnosząc się do tematu konferencji i jej teoretyczno-praktycznego charakteru, podkreślił, że forma ta daje uczestnikom możliwość szerszego spojrzenia na omawiane problemy związane z nielegalną migracją, tym bardziej że poruszane aspekty prezentowane były w sposób interdyscyplinarny, na gruncie prawa administracyjnego, karnego i finansowego oraz politologii i socjologii.

Drugiej części obrad przewodniczył prof. zw. dr hab. Stanisław Pieprzny, a wystąpienia w niej mieli: dr hab. prof. UR Anna Golonka - kierownik Zakładu Prawa Karnego WPiA UR, dr Małgorzata Trybus - Zakład Prawa Karnego WPiA UR, podinspektor Barłłomiej Kowalski - naczelnik Wydziału do spraw Walki z Przestępczością Gospodarczą Komendy Wojewódzkiej Policji w Rzeszowie oraz dr Michał Ura - Katedra Prawa Konstytucyjnego WPiA UR. Prof. A. Golonka ukazała „Prawnokarne aspekty przeciwdziałania finansowaniu terroryzmu", wskazując na zjawisko prania brudnych pieniędzy i finansowania terroryzmu, a dr M. Trybus podzieliła się uwagami na temat „Przestępstw nielegalnej migracji w świetle przepisów kodeksu karnego". Interesujące wystąpienie miał podinsp. B. Kowalski, który przygotował referat dotyczący „Dynamiki przestępczości cudzoziemców na terenie województwa podkarpackiego". Zwrócił m.in. uwagę na występowanie przestępczości podatkowej (przemyt towarów, wyroby akcyzowe), przestępczości przeciwko wiarygodności dokumentów, przeciwko porządkowi publicznemu i bezpieczeństwu w komunikacji. Ponadto wskazał, że zjawiskiem negatywnym, wpływającym na bezpieczeństwo, aczkolwiek dozwolonym w świetle przepisów, jest współrejestrowanie pojazdów przez obywateli Polski i Ukrainy. Przedstawiając dane na temat przestępstw popełnianych przez cudzoziemców, referujący zastrzegł, że rzeczywista liczba sprawców 
i czynów przez nich popełnionych znacznie przekracza oficjalne dane statystyczne. Skala przestępstw popełnianych przez cudzoziemców może być znacznie zaniżona w statystykach ze względu na ich słabą wykrywalność. Wiąże się to przede wszystkim z hermetycznością niektórych grup (np. Wietnamczyków) oraz z tym, że nierzadko wolą oni unikać kontaktów z policją i rozwiązywać wszelkie spory i konflikty w obrębie własnej społeczności. Ponadto występują trudności w weryfikowaniu danych. Referujący wskazał też na dużą liczbę zdarzeń, w których cudzoziemcy są pokrzywdzonymi, a nie popełniającymi przestępstwa.

Przedstawiając referat na temat "Wybranych problemów stosowania prawa wobec cudzoziemców", dr M. Ura zwrócił uwagę na występujące luki prawne związane z rejestracją działalności gospodarczej przez cudzoziemców i możliwości nadużywania prawa, ale co istotne, w majestacie prawa.

Na zakończenie odbyła się dyskusja, w czasie której podkreślano ważność podnoszonych w referatach kwestii. Zwracano też uwagę na nazewnictwo, które media i politycy wypaczają. Nie każdy bowiem cudzoziemiec jest uchodźcą. Warunki uzyskania statusu uchodźcy określają przepisy i status ten uwarunkowany jest uprzednim postępowaniem administracyjnym. Nie można więc generalnie mówić o migrantach jako uchodźcach.

Kolejny dzień obrad rozpoczął się częścia, której przewodniczyła prof. E. Feret. Referaty zaprezentowali: mgr Jakub Majewski - Kancelaria Adwokacka Uralegal „Efektywność dochodzenia należności od cudzoziemców prowadzących działalność gospodarczą na terenie RP", mgr Sylwia Mazur - Wydział Administracji i Nauk Społecznych Wyższej Szkoły Informatyki i Zarządzania w Rzeszowie „Zaprojektowany, by rozczarować? Wspólny Europejski System Azylowy - pomiędzy ochroną praw człowieka a interesami państw członkowskich UE", mgr Agnieszka Baran - Wydział Spraw Obywatelskich i Cudzoziemców Podkarpackiego Urzędu Wojewódzkiego "Zatrudnianie cudzoziemców - wybrane problemy na przykładzie województwa podkarpackiego", mgr Adam Tuleja - Okręgowy Inspektorat Pracy w Rzeszowie „Kontrole legalności zatrudnienia cudzoziemców prowadzone przez PIP w świetle obowiązujących przepisów", Joanna Łubina - studentka WPiA UR "Zatrudnianie cudzoziemców w Polsce - bariery i perspektywy zmian".

Drugiej części obrad przewodniczył ks. dr hab. prof. KUL Sławomir Fundowicz kierownik Katedry Prawa Administracyjnego KUL, a referaty przedstawili: dr hab. prof. UR Eugeniusz Moczuk - kierownik Zakładu Nauk o Bezpieczeństwie i Kryminalistyki WPiA UR „Bezpieczeństwo migracyjne Polski w opiniach studentów Uniwersytetu Rzeszowskiego”, mgr inż. Zbigniew Meducki „Rola i zadania służby leśnej w sytuacji niekontrolowanej migracji", mgr Jakub Dzik - zastępca dyrektora Wydziału Bezpieczeństwa i Zarządzania Kryzysowego Podkarpackiego Urzędu Wojewódzkiego „Funkcjonowanie systemu zarządzania kryzysowego w przypadku wystąpienia masowego napływu uchodźców", Małgorzata Kuczera - studentka WPiA UR "Obowiązki i uprawnienia funkcjonariusza Policji wykonującego czynności z udziałem cudzoziemca".

Dyskusja w drugim dniu obrad, podobnie jak wcześniejsza, dotyczyła nie tylko tematów prezentowanych w wystąpieniach, ale sięgała dalej i odnosiła się też do problemów bezpieczeństwa globalnego, sytuacji migracyjnej w Niemczech, zamachów terrorystycznych i zagrożeń terrorystycznych w państwach europejskich, 
w tym w Polsce. Dyskutanci podkreślali trafność tematu konferencji oraz potrzebę kolejnych konferencji na temat migracji i bezpieczeństwa państwa - z szerszym udziałem przedstawicieli wszystkich służb mundurowych, administracji rządowej ogólnej i samorządowej.

Michat Ura, Wojciech Zając DOI: 10.14746/spp.2016.4.16.13 